\title{
Synaptic and Nonsynaptic Localization of the GluR1 Subunit of the AMPA-Type Excitatory Amino Acid Receptor in the Rat Cerebellum
}

\author{
Agnès Baude, Elek Molnár, Diane Latawiec, R. A. Jeffrey Mcllhinney, and Péter Somogyi \\ Medical Research Council, Anatomical Neuropharmacology Unit, University of Oxford, OX1 3TH Oxford, United Kingdom
}

The cellular and subcellular distribution of the GluR 1 subunit of the AMPA-type excitatory amino acid receptor was determined in the cerebellar cortex of rat using immunocytochemistry. Two polyclonal antibodies were raised against the $\mathbf{N}$ - and $\mathrm{C}$-terminal regions of the subunit. They both labeled a band in immunoblots of rat cerebellar membranes with a molecular weight corresponding to that predicted for this subunit of $105 \mathrm{kDa}$ molecular mass.

In light microscopy the distribution of immunoreactivity for the two antibodies was very similar. The molecular layer was strongly immunoreactive whereas no labeling was observed in the granular layer. Electron microscopy revealed that the antibody raised against the $\mathbf{N}$-terminal part of the subunit recognizes an extracellular epitope(s), whereas the antibody against the $C$-terminal part recognizes an intracellular epitope(s) along the plasma membrane. In Bergmann glial cells the endoplasmic reticulum, Golgi apparatus, and multivesicular bodies were labeled, presumably demonstrating sites of synthesis and degradation for the GluR1 subunit, respectively. Immunoreactivity was associated with Bergmann glial processes surrounding Purkinje cell dendrites, spines, and the glutamate-releasing axon terminals of the parallel and climbing fibers. This suggests that the neurotransmitter glutamate and the AMPA-type glutamate receptors are involved in neuronal/glial communication. The GluR1 subunit was also found at glial membranes in contact with other glial cells.

Purkinje cells showed immunoreactivity in the endoplasmic reticulum and multivesicular bodies. No immunoreaction was detected in basket and stellate cells. Immunoreactivity was observed at type 1 synaptic junctions, including the synaptic cleft. These synaptic junctions were between spines, often originating from Purkinje cell dendrites, and parallel or climbing fiber terminals. Our results demonstrate that the GluR1 subunit of the AMPA-type ionotropic excitatory amino acid receptor is present at both parallel and climbing fiber synapses, which are surrounded by glial processes containing the same receptor subunit.

[Key words: excitatory amino acid receptors, glutamate receptor subunit, AMPA, anti-peptide antibodies, immunocytochemistry, cerebellum, synapse]

\footnotetext{
Received Feb. 26, 1993; revised Aug. 16, 1993; accepted Oct. 26, 1993.

We are grateful to J. David B. Roberts for excellent technical assistance and to Frank Kennedy and Paul Jays for photographic assistance. Agnès Baude was supported by Commission of European Communities Fellowship ERB CHB ICT 920036.

Copyright (c) 1994 Society for Neuroscience $0270-6474 / 94 / 142830-14 \$ 05.00 / 0$
}

Glutamate, the major excitatory neurotransmitter in the CNS, is involved in many functions of developing and mature brain (for review, see Zorumski and Thio, 1992). Moreover, glutamate plays a crucial role in several cerebral disorders such as epilepsy (for review, see Olney, 1985), hypoxic-ischemic neuronal death (Choi and Rothman, 1990), and other neurodegenerative diseases (for review, see Farooqui and Horrocks, 1991; Meldrum, 1992). The multiple actions of glutamate are mediated through both ionotropic receptors, which are ligand-gated cationic channels (for review, see Monaghan et al., 1989), and metabotropic receptors, which are coupled to G-proteins (Sugiyama et al., 1987). Ionotropic receptors have been classified into three major types, namely, NMDA, $\alpha$-amino-3-hydroxy-5-methyl-4-isoxazole propionate (AMPA), and kainate (KA) receptors, on the basis of their binding of selective agonists (Monaghan et al., 1989; Zorumski and Thio, 1992). Molecular cloning has revealed that NMDA, AMPA, and KA types of receptors are derived from different protein families and are composed of hetero-oligomeric subunits that exhibit considerable sequence heterogeneity (for reviews, see Barnard and Henley, 1990; Gasic and Heinemann, 1991; Gasic and Hollmann, 1992; Nakanishi, 1992).

Many cells express more than one of the four high-affinity AMPA binding subunits of the glutamate receptor in the brain (GluR1-GluR4, or GluRA-GluRD; Keinanen et al., 1990). When these are expressed in Xenopus oocytes, or in transfected cultured cells, they are able to form homomeric ion channels activated by AMPA, KA, or L-glutamate but not by NMDA (Hollmann et al., 1989; Boulter et al., 1990; Keinanen et al., 1990; Sommer et al., 1990). However, when combinations of different subunits are coexpressed, the responses show more similarity to neuronal receptors (Boulter et al., 1990; Keinanen et al., 1990; Nakanishi et al., 1990), suggesting that in vivo synaptic receptors are hetero-oligomers. Expression of the GluR1 or GluR3 subunits, or coexpression of GluR1 and GluR3 subunits in Xenopus oocytes, or transfected cells, results in cationic channels that are permeable to calcium. Calcium permeability is abolished when the GluR2 subunit is coexpressed with the GluR 1 or the GluR3 subunits (Hollmann et al., 1991). In line with the concept that has emerged from studies on $\mathrm{GABA}_{\mathrm{A}}$ and nicotinic ACh receptors (for review, see Betz, 1990), the functional diversity of ionotropic glutamate receptors in the CNS is also probably generated by combining different subunits to form heteromeric receptors. However, the composition of receptor subunits in the membrane of specific cells particularly in relation to specific excitatory amino acid (EAA) afferents is still largely unknown.

The cerebellar cortex provides a good opportunity to examine the differential distribution of receptor subunits, because the cell 
types and the origin and chemical nature of their synaptic inputs are well established and easily recognizable at both light and electron microscopic levels (Ramon y Cajal, 1911 ; Eccles et al., 1967; Palay and Chan-Palay, 1974; Sotelo et al., 1975). Three types of axon terminals are thought to use glutamate as neurotransmitter, namely, the axon terminals of the mossy fibers (Somogyi et al., 1986; Ji et al., 1991), which form synapses with dendrites of granule cells, and the axon terminals of climbing and parallel fibers (Somogyi et al., 1986; Zhang et al., 1990), which terminate on Purkinje, stellate, basket, and Golgi cells. Electrophysiological studies have shown that granule and Purkinje cells are activated by glutamate via several receptor mechanisms (Kano and Kato, 1987; Garthwaitc and Bcaumont, 1989; Knopfel et al., 1990; Perkel et al., 1990; Farrant and Cull-Candy, 1991). Furthermore, the climbing and parallel fiber inputs to Purkinje cells produce strikingly different responses (Eccles et al., 1966a,b; Campbell et al., 1983).

Among the receptors responsible for EAA transmission, subunits of the AMPA-type glutamate receptors are differentially expressed in cerebellar cells. Purkinje cells express subunits 13 (or A-C), granule cells express subunits 2 and 4 (or B and D), and Bergmann glial cells express subunits 1 and 4 (or $A$ and $D$; Keinanen et al., 1990; Monyer et al., 1991; Pellegrini-Giampietro et al., 1991; Burnashev et al., 1992a; Gallo et al., 1992; Lambolez et al., 1992; Sato et al., 1993). Previous immunocytochemical detection of the protein by anti-peptide antisera, raised against the GluR 1 subunit, have given contradictory results. Thus, Rogers et al. (1991) reported the presence of GluR1 in Purkinje cells only, whereas other authors (Blackstone et al., 1992; Martin et al., 1992, 1993) described it in Bergmann glial cells, and Petralia and Wenthold (1992) have described the presence of this subunit in both Bergmann glial and Purkinje cells. In order to establish the location of the AMPA-type glutamate receptor in relation to glutamate-releasing synaptic terminals, we have analyzed the cellular and subcellular distribution of the GluR I subunit, using two anti-peptide antisera raised against the N-and C-terminal parts of the subunit (Molnár et al., 1993). In addition immunoreactive glial and neuronal membranes were examined for their anatomical relationships to adjoining cellular elements.

\section{Materials and Methods}

Preparation of animals and tissue. Thirteen male or female Wistar rats $(100-400 \mathrm{gm})$ were deeply anesthetized with sodium pentobarbital $(150$ $\mathrm{mg} / \mathrm{kg}$, i.p.) and perfused for $1 \mathrm{~min}$ through the aorta with $0.9 \% \mathrm{NaCl}$ solution, followed by $100-300 \mathrm{ml}$ of ice-cold fixative. Fixative contained $4 \%$ paraformaldehyde, $0.025-0.1 \%$ glutaraldehyde, and approximately $0.2 \%$ picric acid made up in 0.1 m phosphate buffer (PB), at $\mathrm{pH} 7.2$ (Somogyi and Takagi, 1982). The duration of perfusion varied from 9 to $30 \mathrm{~min}$. Immunoreactivity could be found with all fixation procedures, but the best results were achieved using the lowest concentration of glutaraldehyde fixative for less than $15 \mathrm{~min}$. After perfusion, the cerebellum was removed, halved sagittally, extensively washed in PB for several hours, and put overnight in PB containing 30\% sucrose at $4^{\circ} \mathrm{C}$ for cryoprotection. The blocks were frozen in liquid nitrogen and immediately thawed in PB. This procedure was adopted to improve the penetration of immunoreagents as described earlier (Somogyi and Takagi, 1982) and to minimize background staining. Sagittal sections were obtained with a vibratome (70-100 $\mu \mathrm{m}$ thick) and collected in PB.

Anti-peptide antibodies to GluRI AMPA receptor subunit. Two attinity-purified rabbit polyclonal antibodies were used. Antibodies were made to synthetic peptides corresponding to residues 253-267 and 877889 of the published amino acid sequence of the GluR 1 subunit from the rat brain (Hollmann et al., 1989). The production and characterization of the antisera have been described previously (Molnár et al., 1993). Briefly, peptides RTSDSRDHTRVDWKR (residues 253-267) and SHSSGMPLGATGL (residues 877-889) were synthesized both as multiple copies on a branching lysyl matrix (multiple antigenic peptides, MAPs) and as conventional linear peptides using solid-phase synthesis. New Zealand White rabbits were immunized with the MAPs without conjugation. Both antisera were purified by affinity chromatography using the corresponding monomeric peptide coupled to Reacti-gel HW65F (Pierce Chemical Co.). To facilitate the reading of this article, both antibodies have been supplied with a short code name (according to the code number of the immunized rabbits) as follows: antibody N12 was raised against the $\mathrm{N}$-terminal residues $253-267$ of the GluR I subunit, and antibody $\mathrm{Cl} 7$ was raised against the $\mathrm{C}$-terminal residues $877-889$. Neither of these sequences have homologies with the other GluR2GluR4 subunits.

Immunoblot of rat cerebellar membranes, probed with anti-GluRI antibodies. Membranes prepared from rat cerebellum (Zukin et al., 1974) were subjected to SDS-polyacrylamide gel electrophoresis $(100 \mu \mathrm{g}$ protein/lane, using $10 \%$ polyacrylamide gels) and immunoblotting using affinity-purified anti-peptide antibodies N12 and C17 (final concentration, $5 \mu \mathrm{g} / \mathrm{ml}$; incubated at $2^{\circ} \mathrm{C}$ for $14 \mathrm{hr}$ ). The bound antibodies were detected by reaction with alkaline phosphatase-conjugated anti-rabbit IgG (Dako, High Wycombe, UK; diluted 1:1000; incubated at room temperature for $2 \mathrm{hr}$ ). The bound conjugated IgG was visualized by reaction with a solution containing $20 \mathrm{ml}$ of $0.1 \mathrm{M}$ Tris- $\mathrm{HCl}(\mathrm{pH} 9.5)$, $0.1 \mathrm{M} \mathrm{NaCl}, 0.05 \mathrm{M} \mathrm{MgCl}_{2}, 50 \mu \mathrm{l}$ of $150 \mathrm{mg} / \mathrm{ml}$ nitroblue tetrazolium in $70 \% N, N$-dimethylformamide (DMF), and $35 \mu \mathrm{l}$ of $50 \mathrm{mg} / \mathrm{ml} 5$-brom4-chlor-3-indolyl-phosphate toluidine salt in DMF.

Immunocytochemistry. Immunocytochemistry was carried out using the avidin-biotinylated horseradish peroxidase complex method $(A B C$, Vector Laboratories). Sections were incubated in $20 \%$ normal goat serum (Vector Laboratories), dissolved in $50 \mathrm{~mm}$ Tris- $\mathrm{HCl}$ buffer, $\mathrm{pH} \mathrm{7.4,}$ containing $0.9 \% \mathrm{NaCl}$ (TBS) for $1 \mathrm{hr}$ at room temperature, and then in primary antibody for $2 \mathrm{hr}$ at room temperature or overnight at $4^{\circ} \mathrm{C}$. Antibodies to the GluR 1 subunit of the AMPA-type receptor were used at a final protein concentration of $0.5-1 \mu \mathrm{g}$ protein $/ \mathrm{ml}$ for antibody $\mathrm{N} 12$, and of $2-4 \mu \mathrm{g}$ protein $/ \mathrm{ml}$ for antibody $\mathrm{C} 17$. After several washes in TBS, the sections were incubated for $2 \mathrm{hr}$ in biotinylated goat antirabbit IgG diluted 1:50 (Vector Laboratories), and then for $2 \mathrm{hr}$ in ABC diluted 1:100 both dissolved in TBS. Triton X-100 (0.3\%) was used in all incubation and washing solutions for the light microscopic studies. The bound antibody was detected by incubation of the sections with $3-3^{\prime}$ diaminobenzidine tetrahydrochloride $(0.05 \%$ in $50 \mathrm{~mm}$ Tris- $\mathrm{IICl}$ buffer, $\mathrm{pH} 7.6$ ) and $0.01 \%$ hydrogen peroxide. The peroxidase reaction end-product was enhanced by treatment with osmium tetroxide (approximately $0.04 \%$ in $\mathrm{PB}, 10 \mathrm{~min}$ ) before dehydration. Sections for light microscopy were mounted on gelatine-coated slides, allowed to dry overnight, dehydrated in graded ethanol and xylene, and finally covered in DePeX under a coverslip.

Sections for electron microscopic studies were successively put in osmium tetroxide ( $1 \%$ in PB, $1 \mathrm{hr}$ ), washed in distilled water, stained in uranyl acetate solution $(1 \%$ in distilled water, $1 \mathrm{~h})$, and then dehydrated in graded ethanol and propylene oxide before impregnation overnight in Epoxy resin (DURCUPAN ACM, Fluka Chemicals Ltd.). The sections were flat-embedded between slide and coverslip and the resin was allowed to polymerize at $56^{\circ} \mathrm{C}$ for $48 \mathrm{hr}$. Areas of the cerebellar cortex were selcetcd from light microscopic examination according to their immunoreactivity, cut and reembedded for ultrathin sectioning. Fifteen blocks (from eight different animals) and 11 blocks (from five different animals) were examined for antiserum N12 and antiserum $\mathrm{C} 17$, respectively. No lead staining was used.

\section{Results}

Antibodies N12 and C17. Both antibodies labeled a $105 \mathrm{kDa}$ band on immunoblots of rat cerebellar membranes (Fig. 1), which corresponded to the predicted molecular mass of the GluR1 subunit (Hollmann et al., 1989). Moreover, antibodies to residues 253-267 and 877-889 have been shown to immunoprecipitate $44 \pm 4 \%$ and $15 \pm 9 \%$ of solubilized ${ }^{3} \mathrm{H}$-AMPA binding activity, respectively, from cerebellum (Molnár et al., 1993). These results indicate that the antibodies interact with AMPA receptors.

Small molecular-weight differences can be observed between the receptor proteins recognized by the two antisera. The band 


\section{$\mathrm{N} 12 \quad \mathrm{C} 17$}

\section{$\mathrm{kD}$ \\ $200-$}

116

$97-$

$66-$

$45-$

$29-$

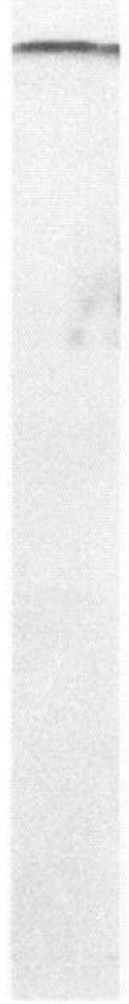

Figure 1. Immunoblots of proteins from rat cerebellar membranes, probed with antibodies raised against the GluR 1 subunit of the AMPA receptor. Both antibodies $\mathrm{N} 12$ and $\mathrm{C} 17$ selectively labeled a $105 \mathrm{kDa}$ protein. The positions of the molecular mass standards are indicated on the left.

labeled with antiserum $\mathrm{C} 17$ migrated slightly faster during SDSPAGE than the one labeled with antiserum N12. The existence of at least two isoforms of GluR 1 glutamate receptor subunit has been suggested based on exhaustive immunoprecipitation experiments (Molnár et al., 1993). These results indicate that variants of GluR1 subunit consist of a common N-terminal region but a distinct $\mathrm{C}$-terminus with probably slight differences in their molecular weights.

Light microscopic analysis of immunoreactivity for the GluRI subunit of the AMPA receptor. Immunoreactivity for the GluR 1 subunit was detected in the molecular layer (Fig. 2) of the rat cerebellum (13 positive results for 13 animals for antiserum N12; 6 positive results for 7 animals for antiserum $\mathrm{C17}$ ). The intensity of immunoreaction varied slightly from one experiment to another but the overall pattern of immunoreactivity was always the same. The intensity of reaction was not significantly different between the different folia, and the distribution was similar with both antibodies (Fig. $2 A, B$ ).

Immunoreactivity for the GluR 1 subunit was associated with the radial processes of Bergmann glial cells, but this staining was more conspicuous when antibody $\mathrm{C} 17$ was used (Fig. $2 B$ ). The cytoplasm of Bergmann glial cells was immunoreactive for the subunit as detected with both antibodies (Fig. 2D,E).

Immunoreactivity enveloped the large dendrites of Purkinje cells throughout the molecular layer (Fig. $2 C$ ), and rarely also their somata. The cytoplasm of Purkinje cclls was weakly stained by both antisera (Fig. $2 D, E$ ). The interpretation of this staining at light microscope level was difficult because weak intracytoplasmic labeling can often be seen in Purkinje cells with many nonimmune sera. However, absorption of purified antibodies to the respective peptides in our experiments abolished the somatic staining, indicating that it was due to the anti-peptide antibodies. Furthermore, electron microscopic examination revealed that the reaction end-product was selectively associated with particular cell organelles (see below).

No immunoreactivity was detected in the somata of basket and stellate cells. The granular layer and the white matter showed no reaction under our conditions.

Subcellular distribution. Immunoreactivity for the GluR1 subunit of the AMPA receptor labeled the same elements with both antibodies. Immunoreactivity with antibodies $\mathrm{N} 12$ or $\mathrm{C} 17$ corresponded to the epitope(s) located at the external or internal face of the plasma membrane, respectively. Similar results were obtained in the rat hippocampus (Molnár et al., 1993).

Immunoreactivity was also found in the endoplasmic reticulum, Golgi apparatus (Fig. 3D) and multivesicular bodies (Fig. $3 A, C)$ of Bergmann glial cells. The somatic membrane of Bergmann glial cells was immunoreactive for the GluR1 subunit as unequivocally demonstrated by the presence of peroxidase endproduct between directly apposed somata when antibody $\mathrm{N} 12$ was used (Fig. $3 A, B$ ). Moreover, immunoreactivity was also detected between adjoining Bergmann glial processes (Fig. $4 A$ ). These results show that the membrane of Bergmann glial cells carries the GluR1 subunit of the AMPA receptor. Immunoperoxidase reaction was associated with Bergmann glial processes following the large dendrites of Purkinje cells (Fig. $4 C$ ), or surrounding the synaptic complex formed by spines and axon terminals in the neuropil of the molecular layer (Fig. 4B). Immunoreactive glial processes were found around the neck of spines emanating from dendritic shafts of Purkinje cells (see Figs. $6 A, 7)$.

Immunoreactivity for the GluR 1 subunit was also associated with the endoplasmic reticulum (Fig. $5 A, B$ ) in the somata of Purkinje cells. This location probably represents the synthesis of the GluR1 subunit in Purkinje cells. The peroxidase endproduct was located inside the cisternae of the endoplasmic reticulum (Fig. $5 B$ ), corresponding to epitopes recognized by antibody $\mathrm{N} 12$ directed to the extracellular N-terminal region.

Figure 2. Light micrographs of immunoreactivity for the GluRl subunit of the AMPA receptor in cerebellar cortex of rat as detected by antibodies $\mathrm{N} 12(A, C, D)$ and $\mathrm{C} 17(B, E) . A$ and $B$, The molecular layer $(\mathrm{ml})$ is strongly immunoreactive, but the granular layer $(\mathrm{gl})$ and the white matter $(\mathrm{wm})$ are not labeled. The black dots seen in the granular layer are red blood cells showing endogenous peroxidase enzyme activity. Radial processes of Bergmann glial cells are particularly well visualized with antibody $\mathrm{C} 17$ (white arrows in $B$ ). Sections in $A$ and $B$ were treated with Triton X-100, and the peroxidase end-product was slightly enhanced with osmium tetroxide (approximately $0.04 \%$ ). $C$, The immunoreactivity forms a coat around 

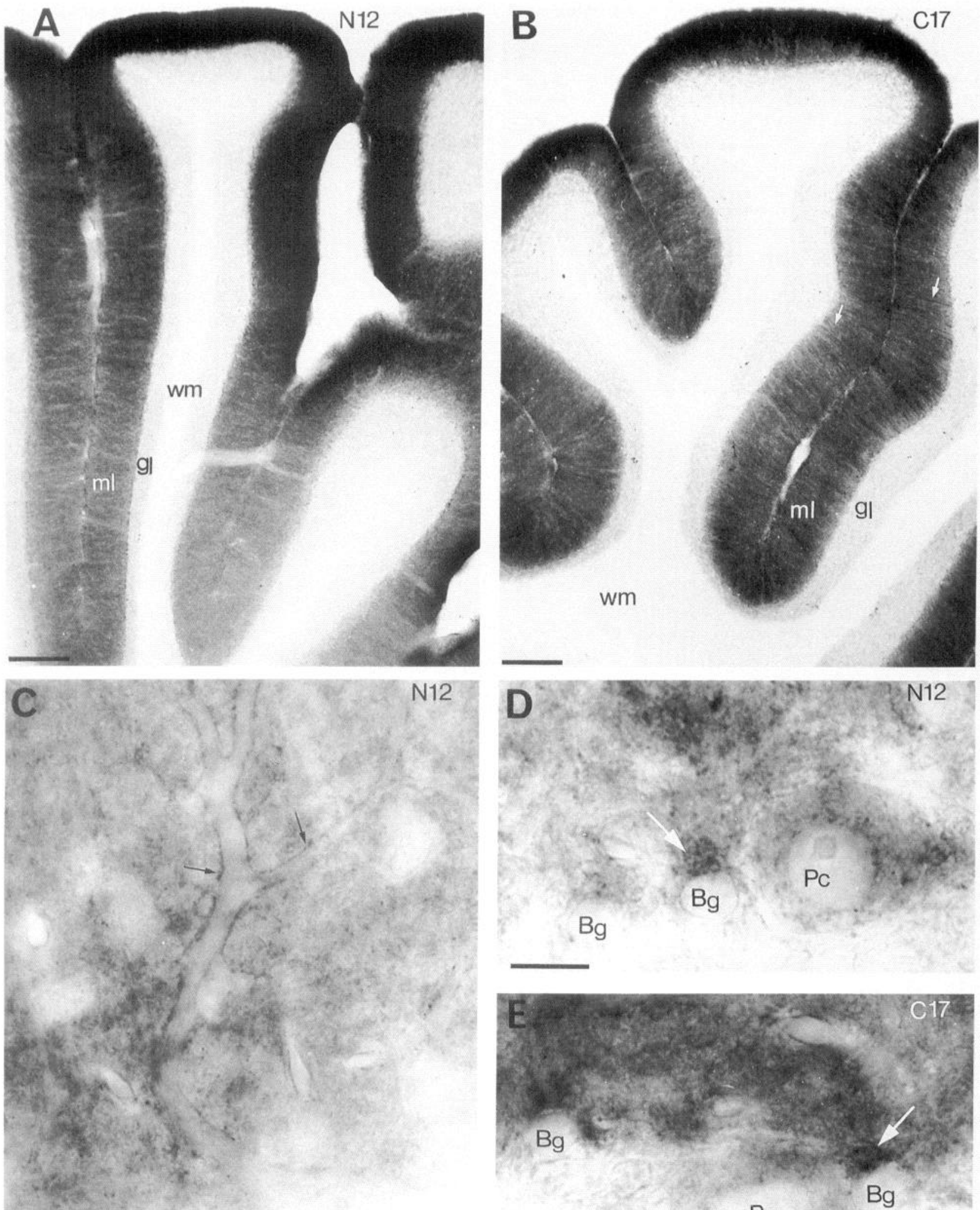

PC

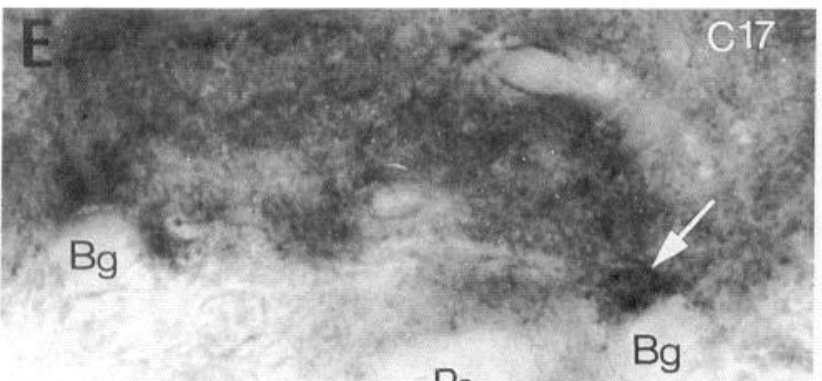

PC

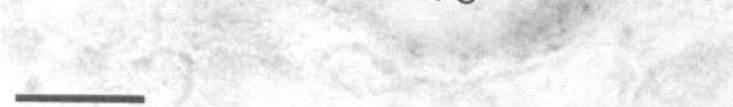

large dendrites of Purkinje cells (arrows) as a result of the high immunoreactivity contained in Bergmann glial processes surrounding the Purkinje cell. $D$ and $E$, Immunoreactivity is detected in the soma of Purkinje cells $(P c)$. The cytoplasm of Bergmann glial cells $(B g)$ is labeled and appears as "triangles" (white arrows) just above their nucleus. The sections in $C-E$ were not treated with Triton X-100. They were treated with $1 \%$ osmium tetroxide and processed for electron microscopic examination. Scale bars: $A$ and $B, 200 \mu \mathrm{m} ; C-E, 10 \mu \mathrm{m}$. 
Moreover, strongly immunoreactive multivesicular bodies were found in soma and primary dendrites (Fig. 5C).

Many type 1 synapses (Gray, 1959), established between spines and axon terminals of parallel fibers, were immunoreactive for the GluR 1 subunit (Figs. $6 A-D, 7 A, B$ ). The peroxidase endproduct filled the synaptic cleft when antibody $\mathrm{N} 12$ was used (Fig. $6 B-D$ ). The extracellular location of the epitope(s) makes the analysis of immunopositive synapses difficult, because it could be argued that the enzyme reaction end-product diffused from neighboring labeled Bergmann glial membranes. However, the presence of the GluR1 subunit of the AMPA receptor at synapses formed between spines and axon terminals of parallel fibers was confirmed with the antibody $\mathrm{C} 17$, which detects the intracellular epitope(s). Indeed, immunoreactivity was found at the intracellular face of postsynaptic membranes using this antibody (Fig. 7B). Synapses established between climbing fiber terminals and spines were also immunopositive for the GluR 1 subunit (Fig. 8). Parallel and climbing fibers terminals were identified according to published fine structural criteria (Eccles et al., 1967; Palay and Chan-Palay, 1974; Sotelo et al., 1975; Dumesnil-Boulez and Sotelo, 1993). Climbing fibers formed large bulbous axon terminals that were filled with densely packed synaptic vesicles, giving them their identifiable dark appearance. They usually established multiple asymmetrical synapses with several spines. Parallel fibers were smaller in diameter and contained relatively fewer synaptic vesicles mostly aggregated at the presynaptic membrane. They usually established a single asymmetrical synapse with a spine. Some boutons were difficult to classify and were reported as "axon terminal" (Fig. 6C) without identification.

Under our experimental conditions no immunoreactive synapses could be found on dendritic shafts or soma of Purkinje cells where GABAergic stellate and basket cells make synapses. No immunoreaction was observed in soma or dendrites of stellate and basket cells. Immunoreactivity was never observed in the granular layer of cerebellar cortex, especially at synapses between dendrites of granule cells and terminals of mossy fibers, which also use glutamate as neurotransmitter (Somogyi et al., 1986).

Immunocytochemical control experiments. Omission of the primary antiserum during the immunocytochemical procedure yielded no staining of sections. Preabsorption of purified antibodies $\mathrm{N} 12$ and $\mathrm{C} 17$ (one experiment), with the corresponding linear synthetic peptide ( $20 \mu \mathrm{g}$ peptide/ml for the $253-267$ residues and $50 \mu \mathrm{g}$ peptide/ml for the 877-889 residues) for $5 \mathrm{hr}$ at room temperature before application to the sections resulted in the loss of immunoreaction. These experiments demonstrate method specificity. In addition, the replacement of antibodies with the respective preimmune sera (diluted 1:1000, one experiment) resulted in a uniform staining of all cells in the cerebellar cortex, in both the molecular and granular layers; the large soma of the Purkinje cells appeared slightly darker than the rest of the cells, especially with the preimmune sera corresponding to antibody $\mathrm{N} 12$. This nonselective attachment of some IgGs to the sections was not seen with the purified antibodies.

Two different sections (one experiment) incubated with both preimmune sera were also examined by electron microscopy. The reaction end-product was found diffusely over all the intracellular components with preimmune serum from rabbit N12, in marked contrast to the pattern observed with the purified antibodies. Electron microscopic examination of cerebellum, treated with the preimmune sera corresponding to antibodies $\mathrm{N} 12$ or $\mathrm{C} 17$, never showed labeling that resembled the reaction obtained with the purified antisera. No labeling was found in the cisternae of the endoplasmic reticulum, in multivesicular bodies, or in the extracellular space in sections treated with the preimmune serum corresponding to antibody N12. No stained glial processes or synapses were observed using the preimmune serum corresponding to antibody $\mathrm{C} 17$.

\section{Discussion}

The results reported here demonstrate that the same subunit of the ionotropic glutamate receptor is expressed at both the parallel and climbing fibers synaptic junctions on Purkinje cells. The GluR 1 subunit is also present at nonsynaptic sites at the surface of Bergmann glial cells.

Differential cellular localization of the GluRI subunit of the AMPA-type glutamate receptor. The distribution of the immunoreactivity as revealed by both antibodies $\mathrm{N} 12$ and $\mathrm{C} 17$ correlates well with the expression of the mRNA coding for the GluR I subunit in both Purkinje and Bergmann glial cells (Keinanen et al., 1990; Pellegrini-Giampietro et al., 1991; Sato et al., 1993). Two spliced variants ("Flip" and "Flop") exist for the cloned GluR 1-GluR4 subunits, and they are differentially expressed throughout the brain (Sommer et al., 1990). In the cerebellar cortex, Bergmann glial cells predominantly express the Flip version of the GluR I subunit, while the Purkinje cells the Flop version (Monyer et al., 1991; Burnashev et al., 1992a; Lambolez et al., 1992). Antibodics N12 and C17 directed against residues 253-267 and 877-889 should recognize both spliced versions of the GluR1 subunit (Sommer et al., 1990; Molnár et al., 1993). Consequently, the immunoreactivity detected in Bergmann glial cells would correspond mainly to the Flip version and the immunoreactivity in Purkinje cells could correspond primarily to the Flop version of the GluR1 subunit.

The distribution of the immunoreactivity for the GluR 1 subunit of the AMPA-type glutamate receptor in the molecular layer is comparable to the high amount of ${ }^{3} \mathrm{H}$-quisqualate and ${ }^{3} \mathrm{H}$ AMPA binding sites observed in the molecular layer of the cerebellar cortex (Cha et al., 1988; Nielsen et al., 1988). However, in the presence of KSCN, which activates AMPA binding, AMPA displaced less than $50 \%$ of ${ }^{3} \mathrm{H}$-quisqualate binding sites (Cha et al., 1988). The remaining ${ }^{3} \mathrm{H}$-quisqualate binding sites could correspond to binding sites associated with metabotropic glutamate receptors (mGluRs) that are highly expressed in Purkinje cells but not in Bergmann glial cells (Masu et al., 1991). The $1 \alpha$ variant of the mGluRs is localized at both synaptic and

Figure 3. Electron micrographs of immunoreactivity for the GluR 1 subunit of the AMPA receptor in Bergmann glial cells as detected by antibody N12. $A$ and $B$, Extracellular immunoreaction end-product is visible in several places in the neuropil (arrows). Immunoreaction is present between the membranes (facing arrows) of two adjoining Bergmann glial cells $(\mathrm{Bg})$ at sites devoid of gap junctions (open arrows). $C$, Bergmann glial cells contain numerous strongly immunoreactive multivesicular bodies (arrow). $D$, Peroxidase end-product is present inside a cistern of the Golgi apparatus (arrows). $N$, nucleus. Scale bars: $A, 1 \mu \mathrm{m} ; B-D, 0.2 \mu \mathrm{m}$. 


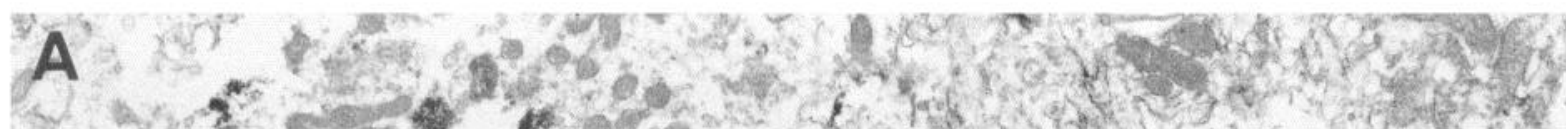

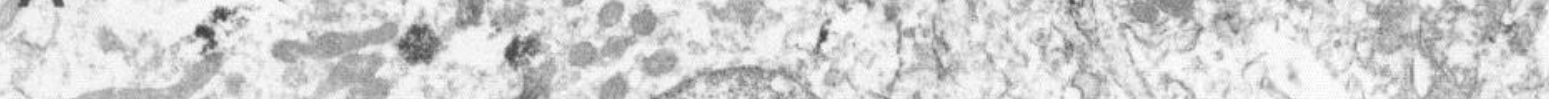

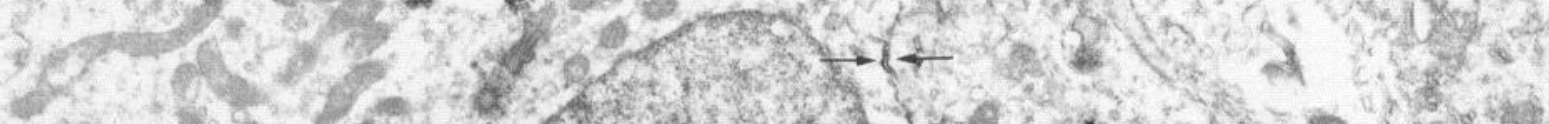

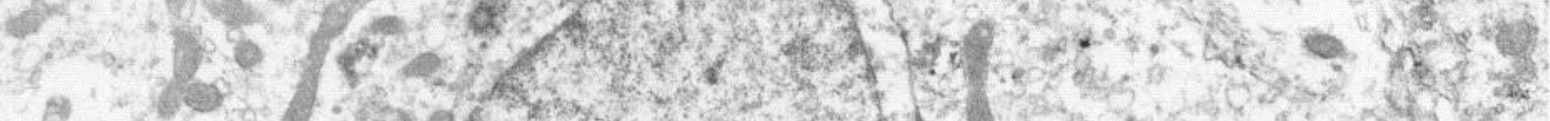

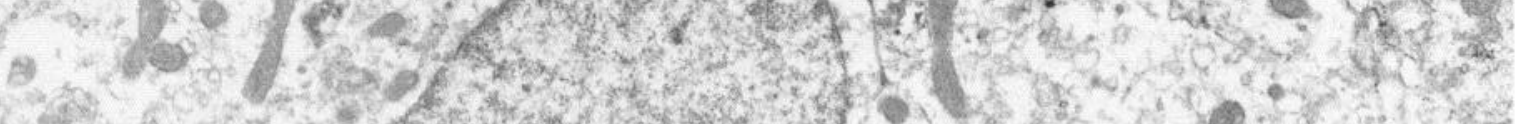

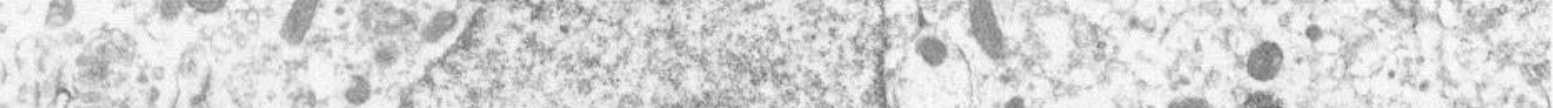

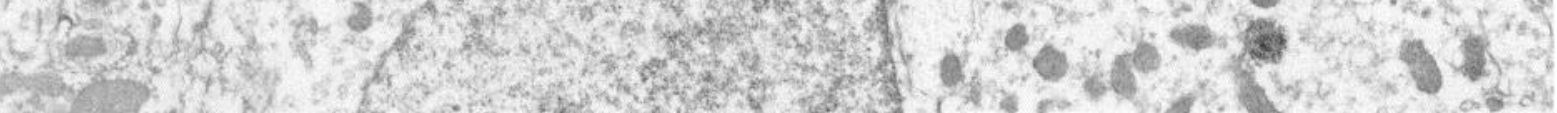

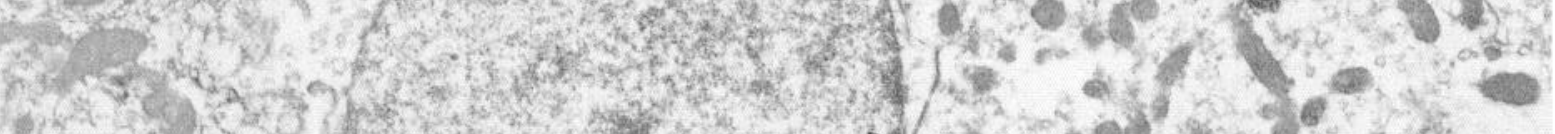

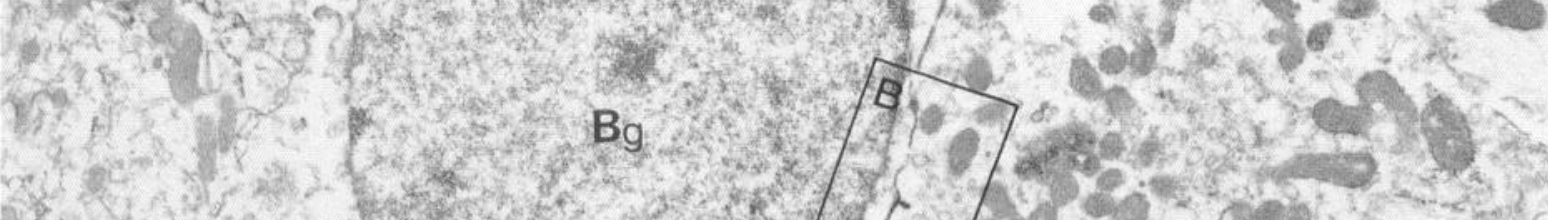

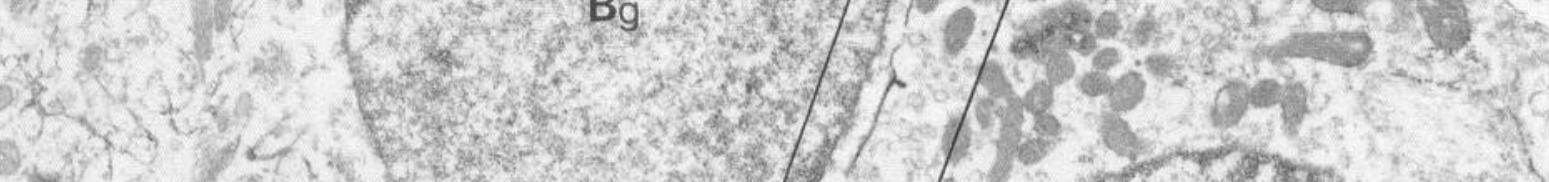

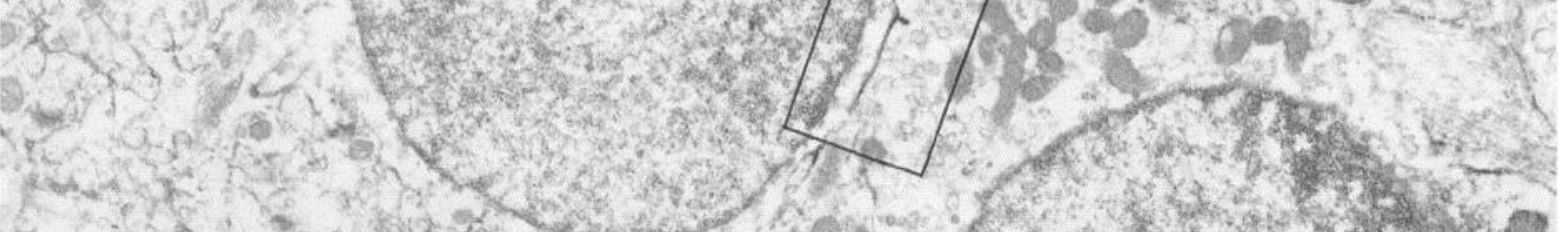

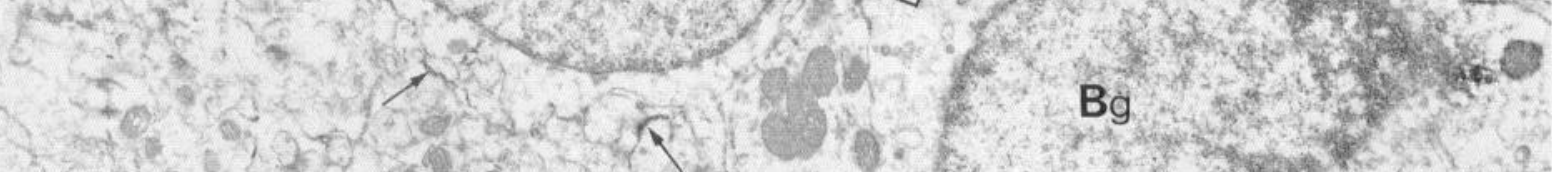

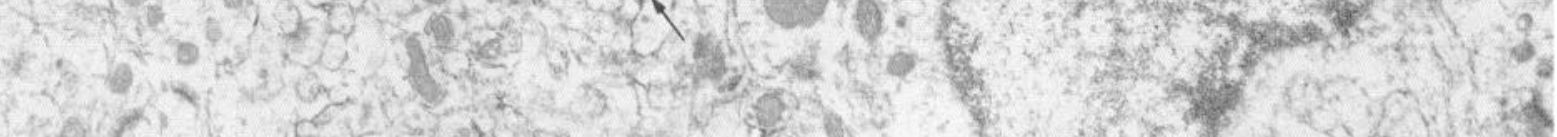

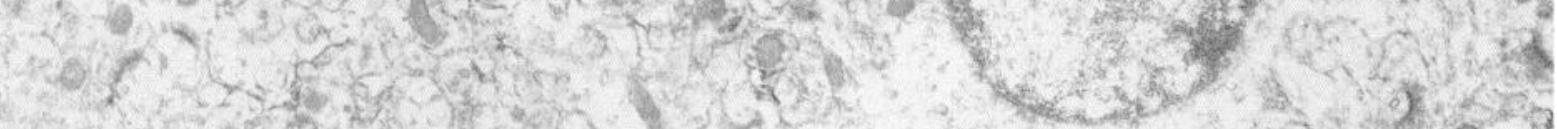

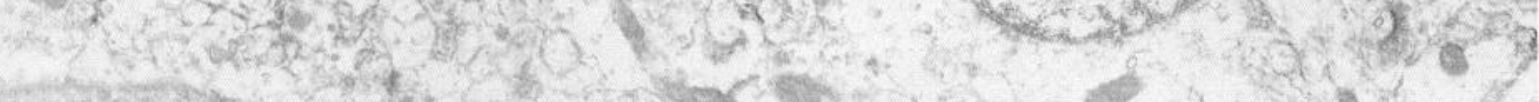
(5)
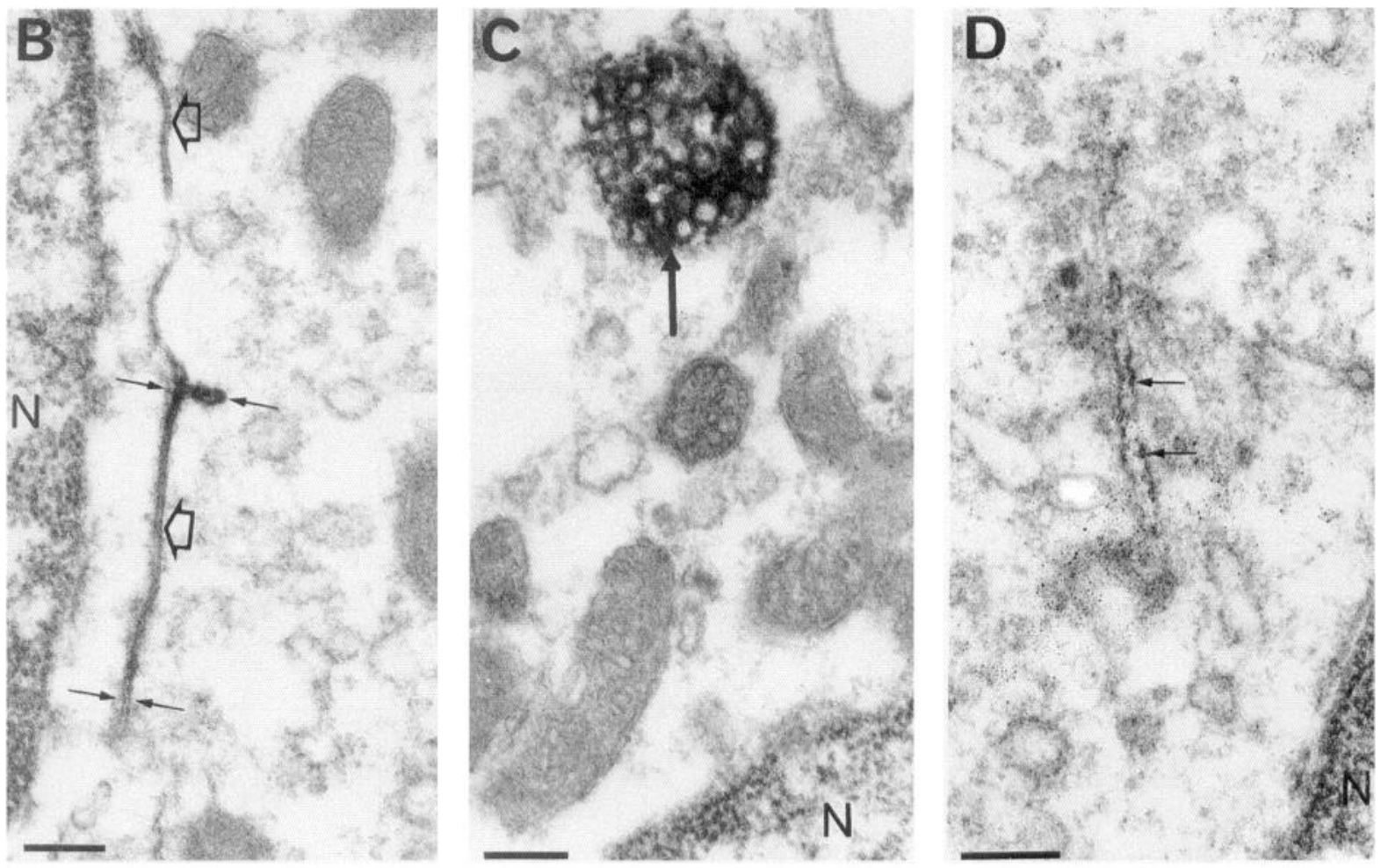

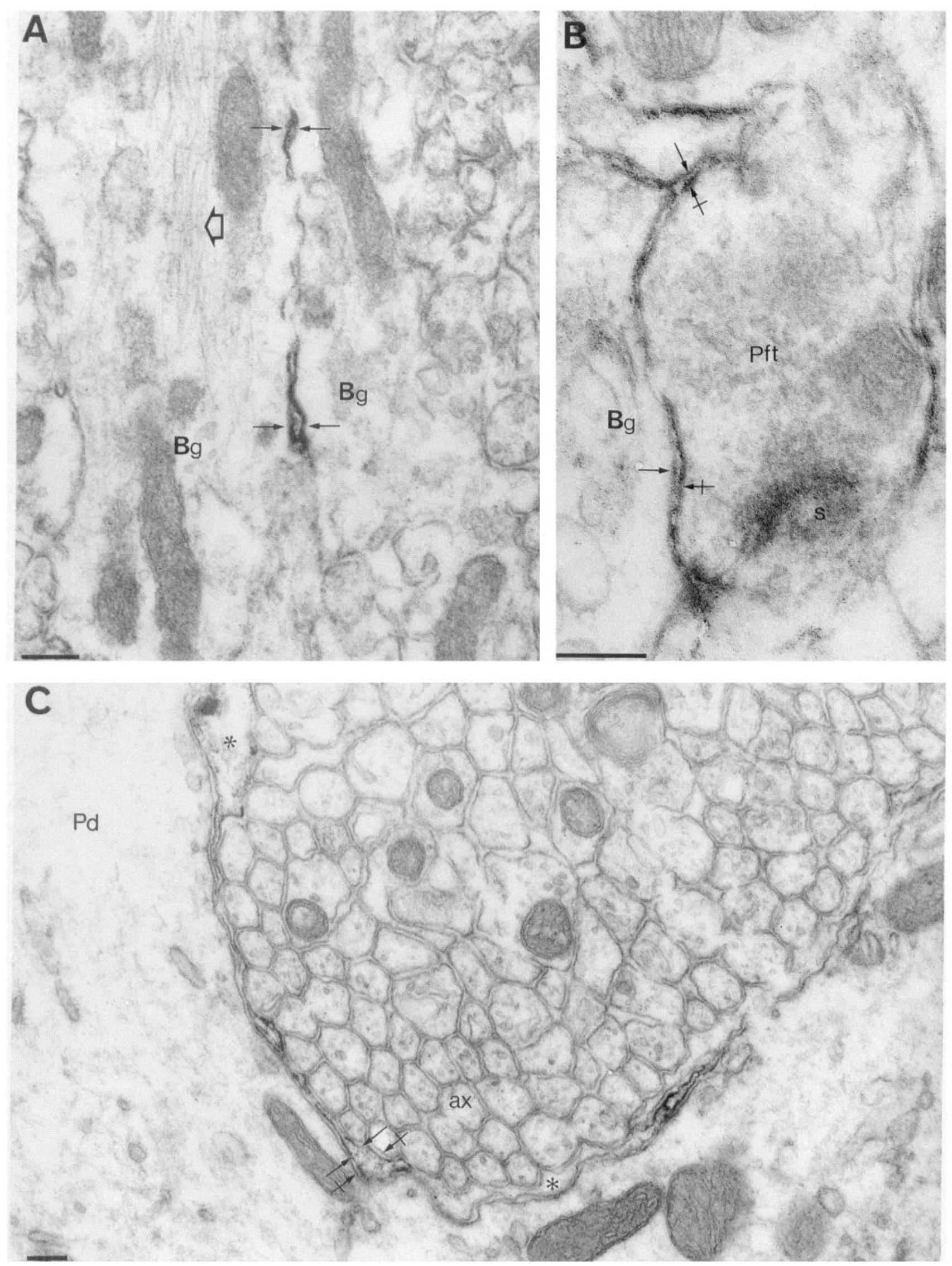

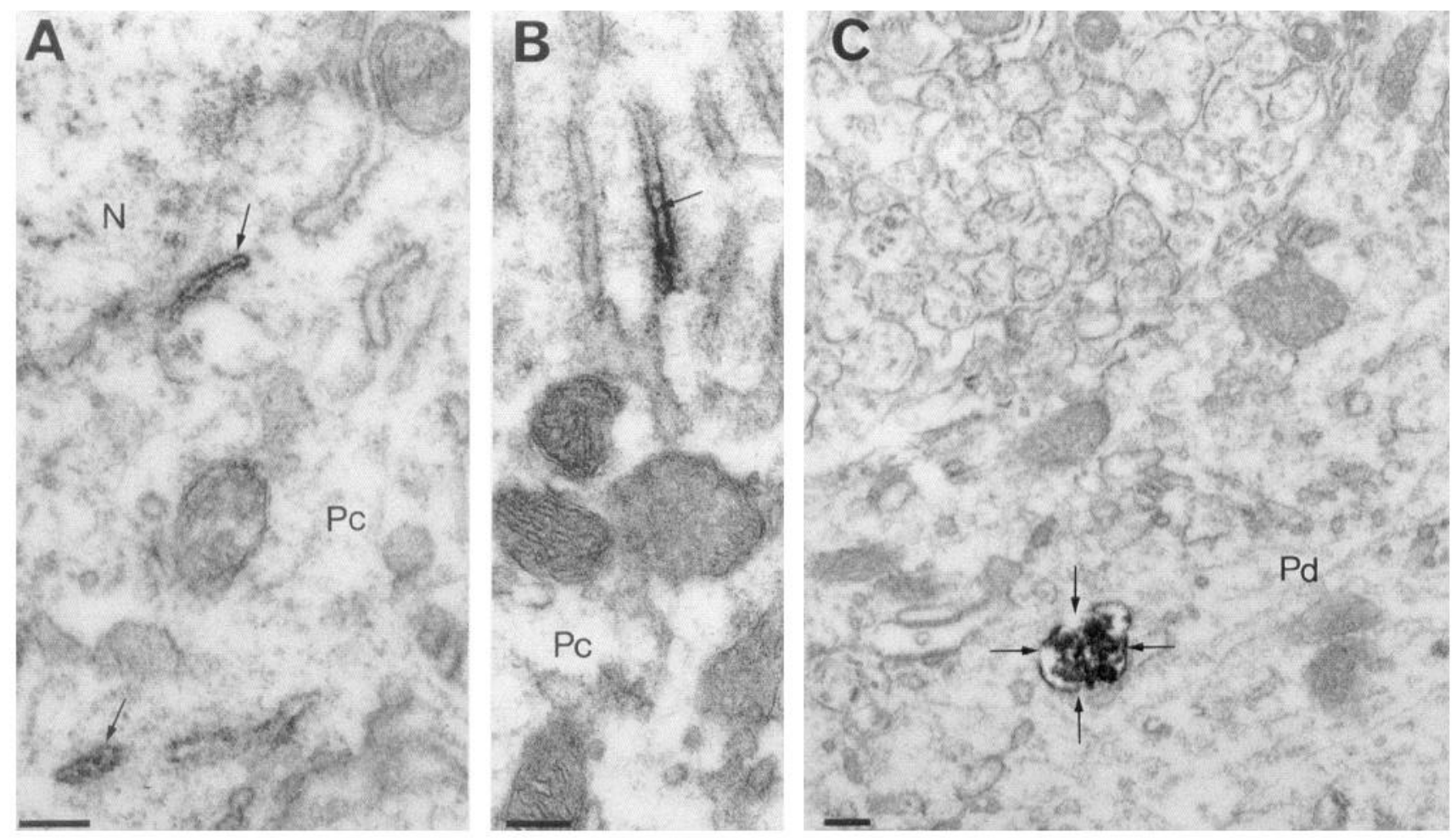

Figure 5. Electron micrographs of the intracellular immunoreactivity for the GluR1 subunit of the AMPA receptor in Purkinje cells $(P c)$ as detected by antibody N12. A, Immunoreactivity is present within cisternae of the endoplasmic reticulum (arrows). B, The peroxidase end-product forms a deposit at the cisternal face of the membrane (arrow). $C$, A multivesicular body is strongly immunoreactive (arrows) in a large dendrite $(P d)$ of a Purkinje cell. $N$, nucleus. Scale bars, $0.2 \mu \mathrm{m}$.

extrasynaptic sites in the Purkinje cell membrane (Martin et al., 1992; Baude et al., 1993; see also below).

Previous immunocytochemical studies using an antiserum prepared against the C-terminal residues $875-889$ of GluR 1 did not report labeling in Purkinje cells (Blackstone et al., 1992; Martin et al., 1992, 1993). Petralia and Wenthold (1992) described immunoreactivity for the GluR1 subunit in both Purkinje and Bergmann glial cells using an antiserum raised against residues $877-889$, similar to antibody $\mathrm{C} 17$ used here. However, the distribution of the peroxidase end-product over most cellular components in these reports (Martin et al., 1992, 1993; Petralia and Wenthold, 1992) differs from the more localized immunoreaction observed in our study. There are two possible explanations for this discrepancy. (1) The diffuse cytoplasmic reaction is due to nonspecific attachment of antibodies to the tissue and this reaction is superimposed on the specific staining. (2) Our antibody $\mathrm{C} 17$ produces a weaker signal and thus only shows sites where the GluR1 subunit is present in high concentration. Only immunoreaction with particulate markers can resolve this question when antibodies directed to intracellular epitopes are used (see Baude et al., 1993). Nevertheless, the location of immunoreactivity inside the cisternae of the endoplasmic reticulum and in multivesicular bodies (as detected with the antibody N12) demonstrates the synthesis and degradation of the GluR 1 subunit in both Purkinje and Bergmann glial cells.

The GluR1 subunit of the AMPA receptor in Bergmann glial cells. The distribution of immunoreactivity in Bergmann glial cells of the rat cerebellum is similar to that found for KA-binding proteins in the submammalian cerebellar cortex (Somogyi et al., $1990 \mathrm{a}, \mathrm{b})$. It was suggested that EAAs could open cationic channels in these cells, leading to depolarization (Somogyi et al., 1990a). Evidence for this hypothesis was found in identified Bergmann glial cells in cerebellar slices (Muller et al., 1992) and cultured glial cells from cerebellum (Burnashev et al., 1992a) showing ion channels operated by EAAs. These mammalian channels were found to be permeable to sodium, potassium, and also calcium, resembling those obtained in Xenopus oocytes, or in human embryonic kidney cells cotransfected with GluR 1 and GluR3 subunits in the absence of the GluR2 subunit (Hollmann et al., 1991; Burnashev et al., 1992b). Indeed, Bergmann glial cells in mammals express mRNAs for the GluR1 and GluR4 subunits but not for the GluR2 subunit (Keinanen et al., 1990;

Figure 4. Electron micrographs of immunoreactivity for the GluR1 subunit of the AMPA receptor in Bergmann glial cells as detected by antibody $\mathrm{N} 12(A$ and $B)$ and antibody $\mathrm{C} 17(C)$. $A$, Immunoreactivity is present between the membranes (facing arrows) of two directly apposed Bergmann glial processes $(B g)$. Note the fibrils characteristic of astrocytes in one of the processes (open arrow). B, A synaptic complex formed between a parallel fiber terminal $(p f t)$ and a spine $(s)$ is surrounded by Bergmann glial processes $(B g)$. Peroxidase end-product fills the extracellular space between the Bergmann glial membranes (arrows) and the membranes of the parallel fiber terminal (crossed arrows). $C$, Bergmann glial processes (asterisks) covering a large Purkinje cell dendrite $(P d)$ show immunoreactivity at the intracellular face of their plasma membrane (arrows) with antibody $\mathrm{C} 17$ that recognizes the intracellular epitope(s). Compare this distribution with that seen in Figure $2 \mathrm{C}$. The crossed arrows point to the membranes of the Purkinje dendrite and of small unmyelinated axons $(a x)$. Scale bars, $0.2 \mu \mathrm{m}$. 


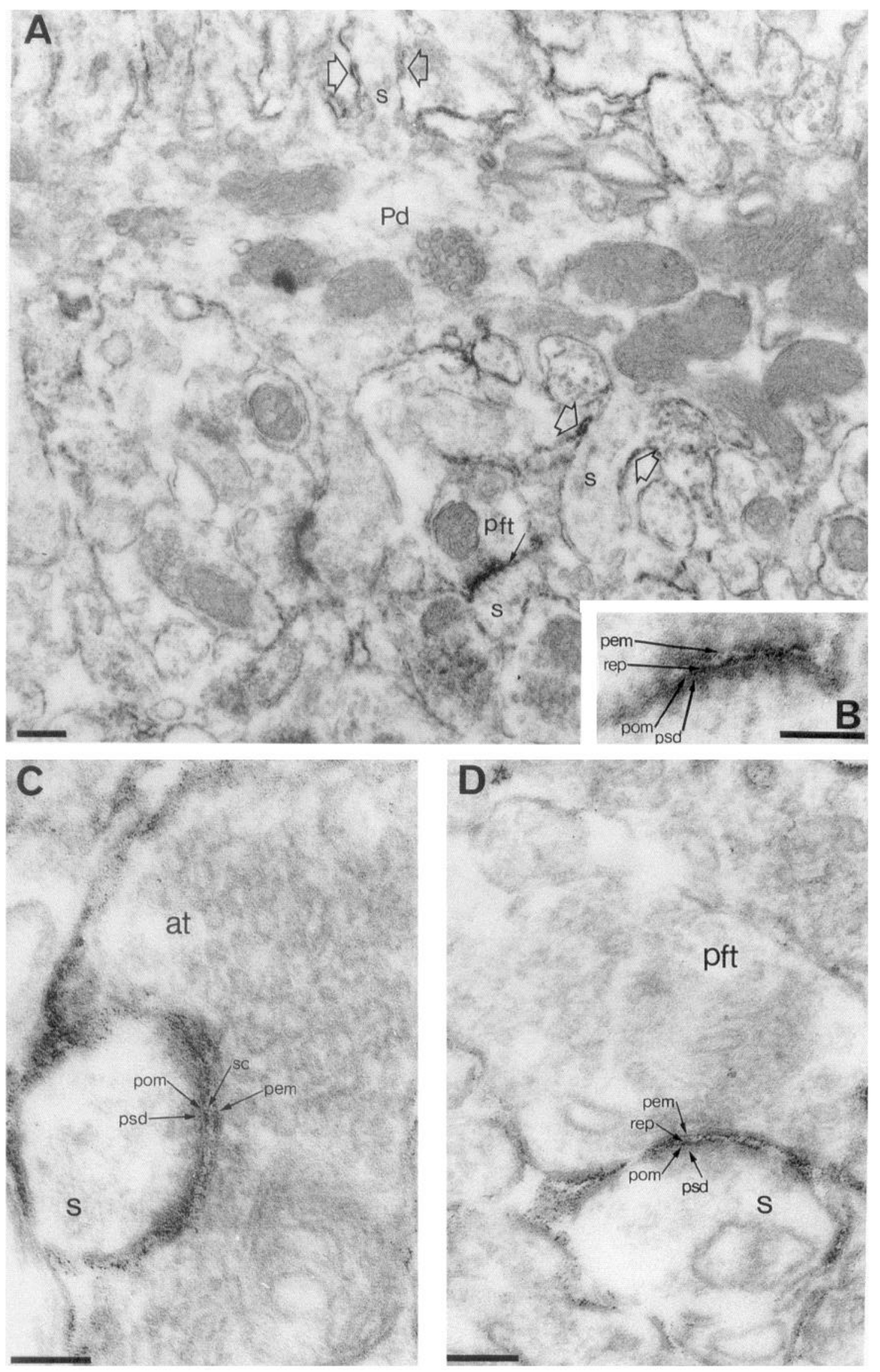



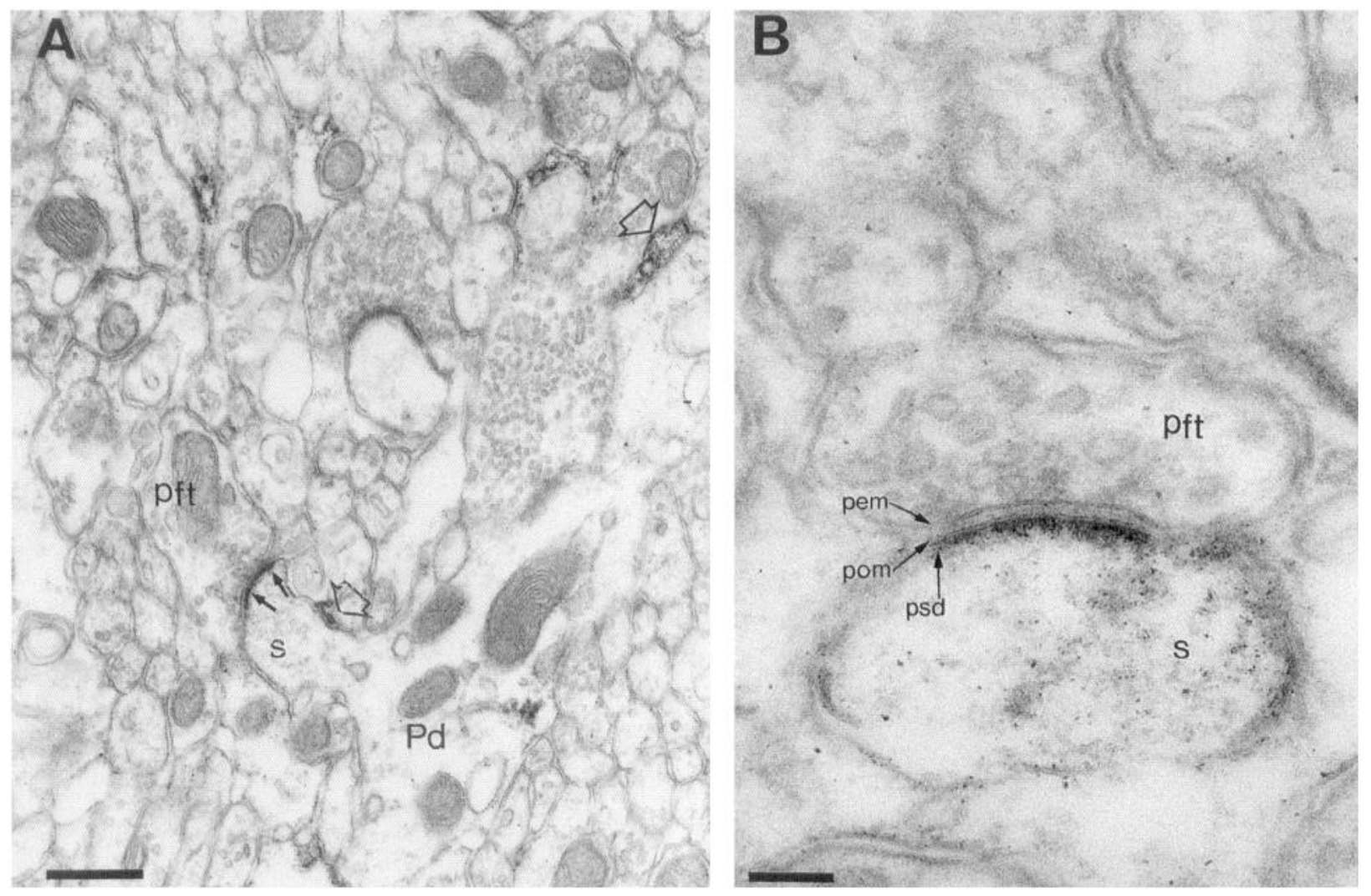

Figure 7. Electron micrograph of the synaptic distribution of immunoreactivity for the GluR1 subunit of the AMPA receptor as detected by antibody C17. $A$, A spine $(s)$ emerging from a Purkinje cell dendrite $(P d)$ establishes an immunopositive type 1 synapse (solid arrows) with a parallel fiber terminal $(p f t)$. Intracellular immunoreactivity is present inside Bergmann glial cell processes along dendritic elements (e.g., open arrow). $B$, The peroxidase reaction end-product labels the postsynaptic density ( $p s d)$ at the intracellular face of the postsynaptic membrane (pom) and not the synaptic cleft between the presynaptic (pem) and postsynaptic (pom) membranes. This contrasts with results shown in Figure 6 for antiserum $\mathrm{N} 12$, and demonstrates that antibody $\mathrm{C} 17$ recognizes the epitope(s) in the intracellular part of GluR1. Scale bars: $A, 0.5 \mu \mathrm{m} ; B, 0.1 \mu \mathrm{m}$.

Burnashev et al., 1992a). The immunoreactive GluRl subunit in the membrane of the Bergmann glial cells demonstrated here probably represents ion channels that allow influx of sodium and calcium when activated by EAAs. Bergmann glial cells have an intimate relationship with Purkinje cell membranes including the spines contacted by parallel and climbing fibers terminals that contain a high concentration of glutamate, the most likely neurotransmitter at these synapses (Somogyi et al., 1986; Garthwaite and Brodbelt, 1989; Ito, 1989; Zhang et al., 1990; Okamoto and Sekiguchi, 1991). It is reasonable to assume that glutamate released from parallel and climbing fiber terminals acts on AMPA receptors in the glial membrane. However, glutamate is thought to be quickly removed from extracellular space by z'utamate transporters located both in the Bergmann glial (Danbolt et al., 1992), and neuronal membranes. It is also rapidly degraded by the enzyme glutamate dehydrogenase (Wenthold c: al., 1987). Therefore, other endogenous agonists, such as hom- ocysteate (Grandes et al., 1991), could also be considered as endogenous ligands for the glial EAA receptors.

Bergmann glial cells (Grandes et al., 1991), like other glial cells in the brain (Kritzer et al., 1992), are rich in the EAA homocysteate. Homocysteate and glutamate are released from cerebellar slices by $\mathrm{K}^{+}$-induced $\mathrm{Ca}^{2+}$-dependent mechanisms (Vollenweider et al., 1990). Upon depolarization Bergmann glia may release homocysteate, which could act on NMDA and/or non-NMDA receptors located at both neuronal and glial membranes as suggested earlier (Grandes et al., 1991). This could explain the presence of immunoreactivity for the GluR 1 subunit at glial-glial contacts where glutamate-releasing axon terminals are not present.

The activation of AMPA-type receptors on Bergmann glial cells may also trigger the release of inhibitory amino acids. For example, it has been shown that cultured cerebellar astrocytes released preloaded GABA after application of KA or glutamate

\footnotetext{
Figure 6. Electron micrographs of the synaptic and extrasynaptic distribution of immunoreactivity for the GluR1 subunit of the AMPA receptor as detected by antibody N12. $A$ and $B$, An immunoreactive type 1 synapse (solid arrow) between a dendritic spine $(s)$ and a parallel fiber terminal $(p f t)$. Note that the neck of other spines (e.g., open arrows) covered by Bergmann glial processes and emanating from a dendritic shaft of a Purkinje cell $(P d)$ is surrounded by immunoreactivity. $B$, Higher magnification of the synapse showed in $A$. The peroxidase reaction end-product (rep) forms rainly a deposit at the extracellular face of the postsynaptic membrane (pom). $C$ and $D$, In more strongly developed reaction the peroxidase reaction end-product (rep) fills the synaptic cleft $(s c)$ between the presynaptic (pem) and the postsynaptic (pom) membranes, demonstrating that antibody N12 recognizes the epitope(s) located at the extracellular region of the transmembrane protein. Note that the postsynaptic densities ( $p s d)$ are not labeled. at, axon terminal. Scale bars: $A, 0.2 \mu \mathrm{m} ; B-D, 0.1 \mu \mathrm{m}$.
} 
Figure 8. Electron micrograph of the synaptic and extrasynaptic (open arrows) distribution of immunoreactivity for the GluR1 subunit of the AMPA receptor as detected by antibody N12. Two spines $(s)$ form immunoreactive type 1 synapses (solid arrows) with a climbing fiber terminal ( $c f t)$. Scale bar, $0.2 \mu \mathrm{m}$.

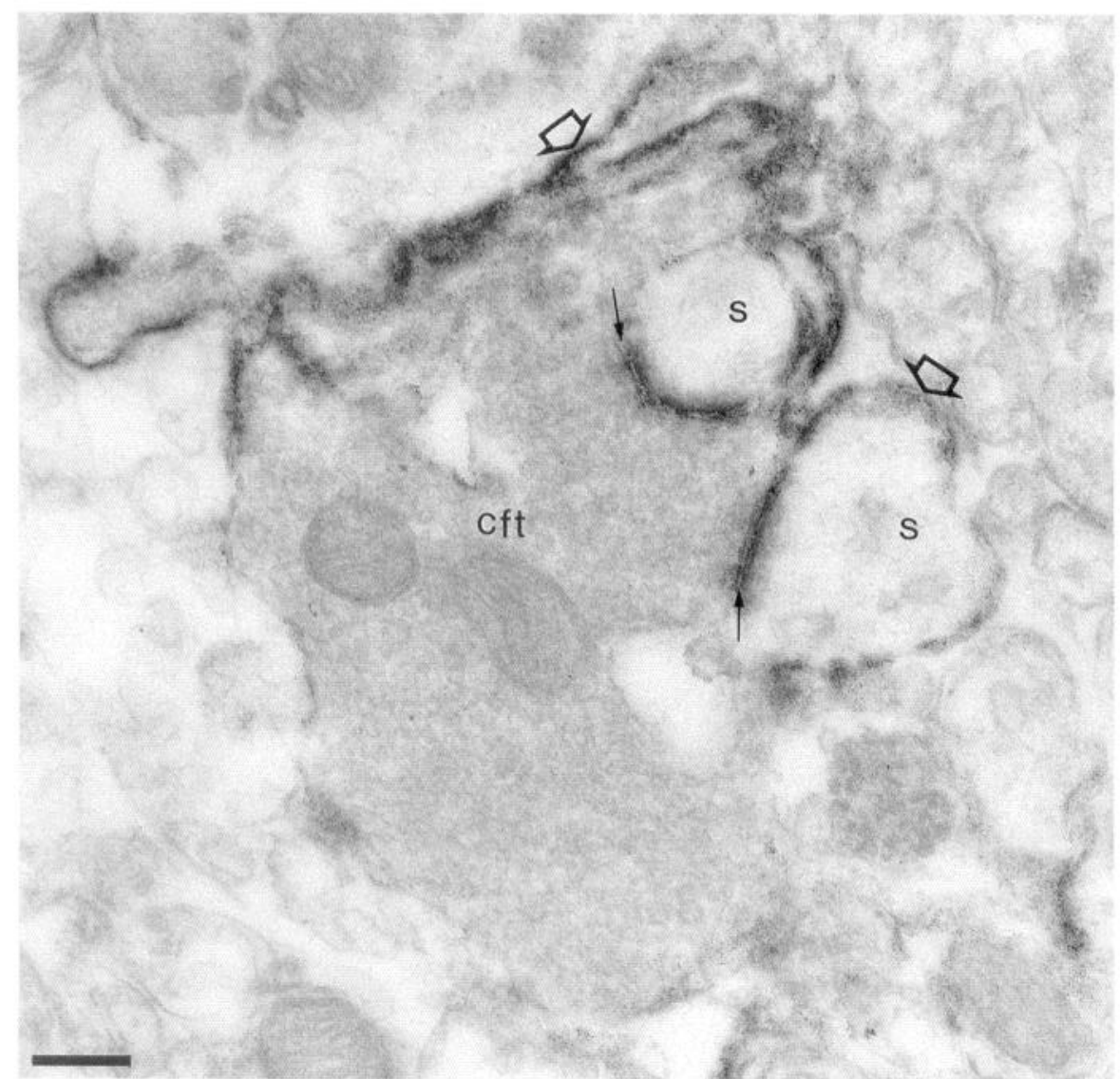

(Gallo et al., 1991). In vivo Bergmann glial cells are able to accumulate GABA (Kelly and Dick, 1975). The activation of glial AMPA receptors could release GABA, which may act on GABA $_{A}$ receptors located on Purkinje cell spines (Somogyi et al., 1989). GABA may also act on the Bergmann glial cells themselves, as they express the $\alpha 2, \beta 3$, and $\gamma 1$ subunits of the $\mathrm{GABA}_{\mathrm{A}}$ receptor (Wisden et al., 1989, 1992).

The GluR1 subunit of the AMPA receptor in neurons. The presence of the GluR1 subunit at synapses established between spines and climbing or parallel fiber terminals is in agreement with electrophysiological experiments showing that the excitatory effect of those inputs on Purkinje cells is mediated by nonNMDA receptors (Kano and Kato, 1987; Garthwaite and Beaumont, 1989; Ito, 1989; Knopfel et al., 1990; Perkel et al., 1990; Farrant and Cull-Candy, 1991). The two major EAA pathways to Purkinje cells have markedly different effects and interact in complex ways (Eccles et al., 1966a,b; Campbell et al., 1983; Ito, 1989), and therefore some differences would be expected in the composition of synaptic receptors. Indeed, a synthetic analog of the Joro spider toxin was found to block parallel fiber but not climbing fiber responses in cerebellar slices (Ajima et al., 1991), suggesting that the composition of the AMPA receptors may be different at the two synapses. Purkinje cells express three subunits of the AMPA receptor GluR1, -2 , and -3 (Sommer et al., 1990; Burnashev et al., 1992a) and also other EAA receptors (Bettler et al., 1990; Werner et al., 1991; Brorson et al., 1992). Further high-resolution immunocytochemical studies are necessary to clarify the distribution of the other subunits at specific synapses in the membrane of Purkinje cells.

It is now certain that at least the parallel fiber terminals exert their effect through several excitatory receptor mechanisms. In addition to the AMPA receptors, the $1 \alpha$ variant (mGluR $1 \alpha$ ) of the mGluR family has also been localized at parallel fiber synapses (Martin et al., 1992; Baude et al., 1993; Görcs et al., 1993). Interestingly, the mGluR $1 \alpha$ is concentrated at the edge of the postsynaptic specialization and at extrasynaptic sites as demonstrated by a sensitive immunogold technique using metal particles as the immunolabel (Baude et al., 1993). Thus, it seems that the subsynaptic plasma membrane of Purkinje cell spines is parceled. The ionotropic AMPA receptors mediating fast glutamate effects are probably concentrated in the synaptic specialization, whereas the mGluR $1 \alpha$ is concentrated at perisynaptic sites and will only be activated by high-frequency stimulus evoked release of glutamate (Baude et al., 1993). Indeed, preferential high-frequency activation of mGluRs has been demonstrated in the hippocampus (Bashir et al., 1993; Miles and Poncer, 1993).

Climbing and parallel fiber terminals also contact dendritic shafts and spines of Golgi, basket, and stellate cells. Considering the large number of spines immunoreactive for the GluR 1 subunit in our study, it is possible that some of the spines belong to these interneurons. However, no immunoreactivity for the GluR 1 subunit could be found in the endoplasmic reticulum or multivesicular bodies in basket, stellate, or Golgi cells. The presence of a low density of the AMPA-type glutamate receptors on these cells cannot be excluded. However, in situ hybridization experiments have failed to detect any of the mRNAs coding for the AMPA receptor subunits in these cells (Burnashev et al., 1992a). Furthermore, the excitation of the GABAergic interneurons of the molecular layer of cerebellum is thought to be mediated by NMDA receptors (Garthwaite and Beaumont, 1989), since NMDA-induced responses of Purkinje cells seem 
to be evoked indirectly and are completely blocked by bicuculline, a $\mathrm{GABA}_{\mathrm{A}}$ receptor antagonist (Kano et al., 1988; Farrant and Cull-Candy, 1991).

The existence of presynaptic NMDA and non-NMDA EAA receptors has been suggested, for example, in hippocampus and striatum (Martin et al., 1991; Desce et al., 1992). However, to our knowledge, previous studies have not predicted presynaptic ionotropic glutamate receptor in the cerebellum. In none of the cerebellar tissues we examined was presynaptic labeling for GluR 1 apparent, in agreement with previous results in the hippocampus (Molnár et al., 1993). The same conclusion was reached in other immunocytochemical studies (Petralia and Wenthold, 1992; Martin et al., 1993). There is considerable evidence that the type 4 metabotropic glutamate receptor (mGluR4), which is preferentially activated by L-2-amino-4phosphonobutyrate, would represent a type of presynaptic glutamate receptor (Thomsen et al., 1992; Tanabe et al., 1993). Cerebellar granule cells highly expressed RNA messengers for mGluR4 (Tanabe et al., 1993), and mGluR agonists are thought to have a presynaptic action at parallel fiber terminals (LarsonPrior et al., 1990; Glaum et al., 1992). It will be interesting to see where the mGluR4 receptor protein is localized at the surface of the membrane of parallel fiber terminals.

The orientation of the GluR1 subunit in the membrane as revealed by immunocytochemistry. It has been suggested that AMPA receptor subunits contain probably four hydrophobic domains that may span the membrane in analogy with other ion channel subunits (Hollmann et al., 1989; Betz, 1990; Gasic and Hollmann, 1992). This conformation, which is largely conjectural, predicts that both the $\mathrm{N}$ - and $\mathrm{C}$-terminal regions should be at the extracellular face of the plasma membrane.

Immunoreactivity obtained with antibodies N12 [residues 253-267 (RTSDSRDHTRVDWKR) were used as antigen] and C17 [residues 877-889 (SHSSGMPLGATGL) were used as antigen] was observed at the extracellular and intracellular faces of the plasma membrane, respectively, as reported earlier in the hippocampus (Molnár et al., 1993). Other immunocytochemical studies using antiserum directed against sequence of the C-terminal part of the GluR 1 subunit (SHSSGMPLGATGL, Petralia and Wenthold, 1992; KMSHSSGMPLGATGL, Martin et al., 1992, 1993) also showed an intracellular immunoreactivity when observed by electron microscopy. Similar results were obtained with other antisera raised against C-terminal parts of other subunits of the AMPA receptor (Petralia and Wenthold, 1992; Martin et al., 1993). In addition, immunoreactive labeling performed on cultured hippocampal neurons and using similar antiserum was only obtained with permeabilized cells, confirming our results (Craig et al., 1993). However, none of these studies addressed the question of the transmembrane conformation of the AMPA receptor subunit, although the finding of intracellular labeling is not in agreement with the presumed extracellular location of the C-tcrminal part of the AMPA receptor subunit.

Immunoreactivity for the $\mathrm{GABA}_{\wedge}$ (Somogyi et al., 1989) and glycine receptors (Triller et al., 1985) has been found at the extracellular face of the plasma membrane when antibodies to the predicted extracellular domains were used (Ewert et al., 1990; Schroder et al., 1991). On the other hand, immunoreactivity for the $\alpha 6$ subunit of the $\mathrm{GABA}_{\mathrm{A}}$ receptor was present at the intracellular face of postsynaptic membrane when detected with an antibody recognizing the putative intracellular loop between the third and fourth transmembrane domains of the subunit (Baude et al., 1992). Using a sensitive immunogold tech- nique in both pre- and postembedding experiments, immunoreactivity for mGluR $1 \alpha$ was located at the intracellular face of postsynaptic elements when an antibody directed against its predicted intracellular C-terminal part was used (Baude et al., 1993). In addition, using a monoclonal antibody directed against the extracellular part of the $\alpha$-subunit of the ACh receptor of the eel's electric organ, immunoperoxidase reaction end-product as well as immunogold particles could be found extracellularly on the surface of cardiac ganglionic cells both at synaptic and extrasynaptic location (Sargent and Peng, 1989). These results suggest that antibodies and high-resolution immunocytochemical techniques can be used as reliable indicator of the location of epitopes in the membrane. The presence of extracellular immunoreactivity with antibody N12 is in agreement with the extracellular location of the N-terminal region of the GluR 1 subunit, as predicted by the present model. However, the intracellular immunoreactivity obtained with antibody $\mathrm{C} 17$ to the C-terminal peptide suggests an intracellular position of this region of the protein.

\section{References}

Ajima A, Hensch T, Kado RT, Itoi M (1991) Differential blocking action of Joro spider toxin analog on parallel fiber and climbing fiber synapses in cerebellar Purkinje cells. Neurosci Res 12:281-286.

Barnard EA, Henley JM (1990) The non-NMDA receptors: types, protein structure and molecular biology. Trends Pharmacol 11:500507.

Bashir ZI, Bortolotto ZA, Davies CH, Berretta N, Irving AJ, Seal AJ, Henley JM, Jane DE, Watkins JC, Collingridge GL (1993) Induction of LTP in the hippocampus needs synaptic activation of glutamate metabotropic receptors. Nature 363:347-350.

Baude A, Sequier J-M, McKernan RM, Olivier KR, Somogyi P (1992) Differential subcellular distribution of the $\alpha 6$ subunit versus the $\alpha 1$ and $\beta 2 / 3$ subunits of the $\mathrm{GABA}_{\mathrm{A}}$ /benzodiazepine receptor complex in granule cells of the cerebellar cortex. Neuroscience 51:739-748.

Baude A, Nusser Z, Roberts JDB, Mulvihill E, Mcllhinney RAJ, Somogyi P (1993) The $1 \alpha$ form of metabotropic glutamate receptor (mGluR $1 \alpha$ ) is concentrated at extra- and perisynaptic membrane of discrete sub-populations of neurons as detected by immunogold reaction in the brain. Neuron 11:771-787.

Bettler B, Boulter J, Hermans-Borgmeyer I, O'Shea-Greenfield A, Deneris ES, Moll C, Borgmeyer U, Hollmann M, Heinemann S (1990) Cloning of a novel glutamate receptor subunit, GluR5: expression in the nervous system during development. Neuron 5:583-595.

Betz H (1990) Ligand-gated ion channels in the brain: the amino acid receptor superfamily. Neuron 5:383-392.

Blackstone CD, Moss SJ, Martin LJ, Levey AI, Price DL, Huganir RL (1992) Biochemical characterization and localization of a non- $N$ methyl-D-aspartate glutamate receptor in rat brain. J Neurochem 58: 1118-1126.

Boulter J, Hollmann M, O'Shea-Greenfield A, Hartley M, Deneris E, Maron C, Heinemann S (1990) Molecular cloning and functional expression of glutamate receptor subunit genes. Science 249:10331037.

Brorson JR, Bleakman D, Chard PS, Miller RJ (1992) Calcium directly permeates kainate/alpha-amino-3-hydroxy-5-methyl-4-isoxazolepropionic acid receptors in cultured cerebellar Purkinje neurons. Mol Pharmacol 41:603-608.

Burnashev N, Khodorova A, Jonas P, Helm PJ, Wisden W, Monyer H, Seeburg PH, Sakmann B (1992a) Calcium-permeable AMPAkainate receptors in fusiform cerebellar glial cells. Science 256:15661570.

Burnashev N, Monyer H, Seeburg PH, Sakmann B (1992b) Divalent ion permeability of AMPA receptor channels is dominated by the edited form of a single subunit. Neuron 8:189-198.

Campbell NC, Ekerot C-F, Hesslow G (1983) Interaction between rcsponses in Purkinje cells evoked by climbing fibre impulses and parallel fibre volleys in the cat. J Physiol (Lond) 340:225-238.

Cha J-H, Greenamyre JT, Nielsen EO, Penney JB, Young AB (1988) Properties of quisqualate $\mathrm{L}-\left[{ }^{3} \mathrm{H}\right]$ glutamate binding sites in rat brain as determined by quantitative autoradiography. J Neurochem 51: $469-478$. 
Choi DW, Rothman SM (1990) The role of glutamate neurotoxicity in hypoxic-ischemic neuronal death. Annu Rev Neurosci 13:171182.

Craig AM, Blackstone CD, Huganir RL, Banker G (1993) The distribution of glutamate receptors in cultured rat hippocampal neurons: postsynaptic clustering of AMPA-selective subunits. Neuron 10:10551068.

Danbolt NC, Storm-Mathisen J, Kanner BI (1992) An $\left[\mathrm{Na}^{+}+\mathrm{K}^{+}\right]$ coupled L-glutamate transporter purified from rat brain is located in glial cell processes. Neuroscience 51:295-310.

Desce JM, Godeheu G, Galli T, Artaud F, Cheramy A, Glowinski J (1992) L-Glutamate-evoked release of dopamine from synaptosomes of rat striatum: involvement of AMPA and $N$-methyl-D-aspartate receptors. Neuroscience 47:333-339.

Dumesnil-Boulez N, Sotelo C (1993) Partial reconstruction of the adult Lurcher cerebellar circuitry by neural grafting. Neuroscience 55:1-21.

Eccles JC, Llinas R, Sasaki K (1966a) The excitatory synaptic actions of climbing fibres on the Purkinje cells of the cerebellum. J Physiol (Lond) 182:268-296.

Eccles JC, Llinas R, Sasaki K (1966b) Intracellularly recorded responses of the cerebellar Purkinje cells. Exp Brain Res 1:161-183.

Eccles JC, Ito M, Szentagothai J (1967) The cerebellum as a neuronal machine. Berlin: Springer.

Ewert M, Shivers BD, Luddens H, Mohler H, Seeburg PH (1990) Subunit selectivity and epitope characterization of $\mathrm{mAbs}$ directed

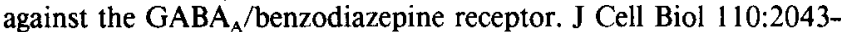
2048

Farooqui AA, Horrocks LA (1991) Excitatory amino acid receptors, neural membrane phospholipid metabolism and neurological disorders. Brain Res̃ Rev 16:171-191.

Farrant M, Cull-Candy SG (1991) Excitatory amino acid receptorchannels in Purkinje cells in thin cerebellar slices. Proc R Soc Lond [Biol] 244:179-184.

Gallo V, Patrizio M, Levi G (1991) GABA release triggered by the activation of neuron-like non-NMDA receptors in cultured type 2 astrocytes is carrier-mediated. Glia 4:245-255.

Gallo V, Upson LM, Hayes WP, Vyklicky L, Winters CA, Buonanno A (1992) Molecular cloning and developmental analysis of a new glutamate receptor subunit isoform in cerebellum. J Neurosci 12: 1010-1023.

Garthwaite J, Beaumont PS (1989) Excitatory amino acid receptors in the parallel fibre pathway in rat cerebellar slices. Neurosci Lett 107:151-156.

Garthwaite J, Brodbelt AR (1989) Glutamate as the principal mossy fibre transmitter in rat cerebellum: pharmacological evidence. Eur J Neurosci 2:177-180

Gasic GP, Heinemann S (1991) Receptors coupled to ionic channels: the glutamate receptor family. Neurobiology 1:20-26.

Gasic GP, Hollmann M (1992) Molecular neurobiology of glutamate receptors. Annu Rev Physiol 54:507-536.

Glaum SR, Slater NT, Rossi DJ, Miller RJ (1992) Role of metabotropic glutamate (ACPD) receptors at the parallel fiber-Purkinje cell synapse. J Neurophysiol 68:1453-1462.

Grandes P, Quang Do K, Morino P, Cuenod M, Streit P (1991) Homocysteate, an excitatory transmitter candidate localized in glia. Eur J Neurosci 3:1370-1373.

Gray EG (1959) Axo-somatic and axo-dendritic synapses of the cerebral cortex: an electron microscope study. J Anat 93:420-433

Hollmann M, O'Shea-Greenfield A, Rogers SW, Heinemann S (1989) Cloning by functional expression of a member of the glutamate receptor family. Nature 342:643-648.

Hollmann M, Hartley M, Heinemann S (1991) $\mathrm{Ca}^{2+}$ permeability of KA-AMPA-gated glutamate receptor channels depends on subunit composition. Science 252:851-853.

Ito M (1989) Long-term depression. Annu Rev Neurosci 12:85-102.

Ji Z, Aas J-E, Laake J, Walberg $F$, Ottersen OP (1991) An electron microscopic, immunogold analysis of glutamate and glutamine in terminals of rat spinocerebellar fibers. J Comp Neurol 307:296-310.

Kano M, Kato M (1987) Quisqualate receptors are specifically involved in cerebellar synaptic plasticity. Nature 325:276-279.

Kano M, Kato M, Chang HS (1988) The glutamate receptor subtype mediating parallel fibre-Purkinje cell transmission in rabbit cerebellar cortex. Neurosci Res 5:325-337.

Keinanen K, Wisden W, Sommer B, Werner P, Herb A, Verdoorn TA, Sakmann B, Seeburg PH (1990) A family of AMPA-selective glutamate receptors. Science 249:556-560.
Kelly JS, Dick F (1975) Differential labeling of glial cells and GABAinhibitory interneurons and nerve terminals following the microinjection of $\left[{ }^{3} \mathrm{H}\right]$ alanine, $\left[{ }^{3} \mathrm{H}\right] D A B A$ and $\left[{ }^{3} \mathrm{H}\right] \mathrm{GABA}$ into single folia of the cerebellum. Cold Spring Harbor Symp Quant Biol 40:93-106.

Knopfel T, Audinat E, Gahwiler BH (1990) Climbing fibre responses in olivo-cerebellar slice cultures. 1. Microelectrode recordings from Purkinje cells. Eur J Neurosci 2:726-732.

Kritzer MF, Cowey A, Ottersen OP, Streit P, Somogyi P (1992) Immunoreactivity for taurine characterizes subsets of glia, GABAergic and non-GABAergic neurons in the neo- and archicortex of the rat, cat and rhesus monkey: comparison with immunoreactivity for homocysteic acid. Eur J Neurosci 4:251-270.

Lambolez B, Audinat E, Bochet P, Crepel F, Rossier J (1992) AMPA receptor subunits expressed by single Purkinje cells. Neuron 9:247258.

Larson-Prior IJ, McCrimmon DR, Slater NT (1990) Slow excitatory amino acid receptor-mediated synaptic transmission in turtle cerebellar Purkinje cells. J Neurophysiol 63:637-650.

Martin D, Bustos GA, Bowe MA, Bray SD, Nadler JV (1991) Autoreceptor regulation of glutamate and aspartate release from slices of the hippocampal CA1 area. J Neurochem 56:1647-1655.

Martin LJ, Blackstone CD, Huganir L, Price DL (1992) Cellular localization of a metabotropic glutamate receptor in rat brain. Neuron 9:259-270.

Martin LJ, Blackstone CD, Levey AI, Huganir L, Price DL (1993) AMPA glutamate receptors subunits are differentially distributed in rat brain. Neuroscience 53:327-358.

Masu M, Tanabe Y, Tsuchida K, Shigemoto R, Nakanishi S (1991) Sequence and expression of a metabotropic glutamate receptor. Nature 349:760-765.

Meldrum BS (1992) Excitatory amino acids receptors and disease. Neurol Neurosurg 5:508-513

Miles R, Poncer J-C (1993) Metabotropic glutamate receptors mediate a post-tetanic excitation of guinea-pig hippocampal inhibitory neurones. J Physiol (Lond) 463:461-473.

Molnár E, Baude A, Richmond SA, Patel PB, Somogyi P, Mcllhinney RAJ (1993) Biochemical and immunocytochemical characterisation of antipeptide antibodies to a cloned GluR 1 glutamate receptor subunit. Cellular and subcellular distribution in the rat forebrain. Neuroscience 53:307-326.

Monaghan DT, Bridges RJ, Cotman CW (1989) The excitatory amino acid receptors: their classes, pharmacology, and distinct properties in the function of the central nervous system. Annu Rev Pharmacol Toxicol 29:365-402.

Monyer H, Seeburg PH, Wisden W (1991) Glutamate-operated channels: developmentally early and mature forms arise by alternative splicing. Neuron 6:799-810.

Muller T, Moller T, Berger T, Schnitzer J, Kettenmann H (1992) Calcium entry through kainate receptors and resulting potassium-channcl blockade in Bergmann glial cells. Science 256:1563-1566.

Nakanishi N, Shneider NA, Axel R (1990) A family of glutamate receptor genes-evidence for the formation of heteromultimeric receptors with distinct channel properties. Neuron 5:569-581.

Nakanishi S (1992) Molecular diversity of glutamate receptors and implications for brain function. Science 258:597-603.

Nielsen EO, Cha J-H, Honore T, Penney JB, Young AB (1988) Thiocyanate stabilizes AMPA binding to the quisqualate receptor. Eur $\mathbf{J}$ Pharmacol 157:197-203.

Okamoto K, Sekiguchi M (1991) Synaptic receptors and intracellular signal transduction in the cerchellum. Neurosci Res 9:213-237.

Olney JW (1985) Excitatory transmitters and epilepsy-related brain damage. In: International review of neurobiology (Smythies JR, Bradley RJ, eds), pp 337-362. San Diego: Academic.

Palay SL, Chan-Palay V (1974) Cerebellar cortex. Cytology and organization. Berlin: Springer.

Pellegrini-Giampietro DE, Bennet MV, Zukin RS (1991) Differential expression of three glutamate receptor genes in developing rat brain: an in situ hybridization study. Proc Natl Acad Sci USA 88:41574161

Perkel DJ, Hestrin S, Sah P, Nicoll RA (1990) Excitatory synaptic currents in Purkinje cells. Proc R Soc Lond [Biol] 241:116-121.

Petralia RS, Wenthold RJ (1992) Light and electron immunocytochemical localization of AMPA-selective glutamate receptors in the rat brain. J Comp Neurol 318:329-354.

Ramon y Cajal S (1911) Histologie du systeme nerveux de l'homme et des vertebrates, Vol 2. Madrid: Maloine. 
Rogers SW, Hughes TE, Hollmann M, Gasic GP, Deneris ES, Heinemann S (1991) The characterization and localization of the glutamate receptor subunit GluR1 in the rat brain. J Neurosci 11:27132724.

Sargent PB, Pang DZ (1989) Acetylcholine receptor-like molecules are found in both synaptic and extrasynaptic clusters on the surface of neurons in the frog cardiac ganglion. J Neurosci 9:1062-1072.

Sato K, Kiyama H, Toyama M (1993) The differential expression patterns of messenger RNAs encoding non- $N$-methyl-D-aspartate glutamate receptor subunits (GluR 1-4) in the rat brain. Neuroscience 52:515-539.

Schroder S, Hoch W, Becker C-M, Grenningloh G, Betz H (1991) Mapping of antigenic epitopes on the $\alpha 1$ subunit of the inhibitory glycine receptor. Biochemistry 30:42-47.

Sommer B, Keinanen K, Verdoorn TA, Wisden W, Burnashev N, Herb A, Kohler M, Takagi T, Sakmann B, Seeburg PH (1990) Flip and flop: a cell-specific functional switch in glutamate-operated channels of the CNS. Science 249:1580-1585.

Somogyi P, Takagi H (1982) A note on the use of picric acid-paraformaldehyde-glutaraldehyde fixative for correlated light and electron microscopic immunocytochemistry. Neuroscience 7:1779-1783.

Somogyi P, Halasy K, Somogyi J, Storm-Mathisen J, Ottersen OP (1986) Quantification of immunogold labelling reveals enrichment of glutamate in mossy and parallel fibre terminals in cat ccrebcllum. Neuroscience 19:1045-1050.

Somogyi P, Takagi H, Richards JG, Mohler H (1989) Subcellular localization of benzodiazepine/GABA $\mathrm{A}_{\mathrm{A}}$ receptors in the cerebellum of rat, cat, and monkey using monoclonal antibodies. J Neurosci 9:2197-2209.

Somogyi P, Eshihar N, Teichberg VI, Roberts JDB (1990a) Cellular and subcellular localization of a putative kainate receptor using a monoclonal antibody in the chick and fish cerebellar cortex. Neuroscience 35:9-30.

Somogyi P, Roberts JDB, Streit P, Hampson DR, Wenthold RJ (1990b) Kainate binding protein (KABP) in the cerebellar cortex; subcellular localization on glial cells as revealed by antibodies to KABP isolated from frog, pigeon and chick. ENA Abstr [Suppl] 3:119.

Sotelo C, Hillman DE, Zamora AJ, Llinas R (1975) Climbing fiber deafferentation: its action on Purkinje cell dendritic spines. Brain Res 98:574-581.

Sugiyama H, Ito I, Hirono C (1987) A new type of glutamate receptor linked to inositol phospholipid metabolism. Nature 325:531-533.
Tanabe Y, Nomura A, Masu M, Shigemoto R, Mizuno N, Nakanishi S (1993) Signal transduction, pharmacological properties, and expression patterns of two rat metabotropic glutamate receptors, mGluR3 and mGluR4. J Neurosci 13:1372-1378.

Thomsen C, Kristensen P, Mulvihill E, Haldeman B, Suzdak PD (1992) L-2-Amino-4-phosphobutyrate (L-AP4) is an agonist at the type IV metabotropic glutamate receptor which is negatively coupled to adenylate cyclase. Eur J Pharmacol 227:361-362.

Triller A, Cluzeaud F, Pfeiffer F, Betz H, Korn H (1985) Distribution of glycine receptors at central synapses: an immunoelectron microscopy study. J Cell Biol 101:683-688.

Vollenweider FX, Cuenod M, Do KQ (1990) Effect of climbing fiber deprivation on release of endogenous aspartate, glutamate and homocysteate in slices of rat cerebellar hemispheres and vermis. J Neurochem 54:1533-1540.

Wenthold RJ, Altschuler RA, Skaggs KK, Reeks KA (1987) Immunocytochemical characterization of glutamate dehydrogenase in the cerebellum of the rat. J Neurochem 48:636-643.

Werner P, Voigt M, Keinanen K, Wisden W, Seeburg PH (1991) Cloning of a putative high-affinity kainate receptor expressed predominantly in hippocampal CA3 cells. Nature 351:742-744.

Wisden W, McNaughton LA, Darlison MG, Hunt SP, Barnard EA

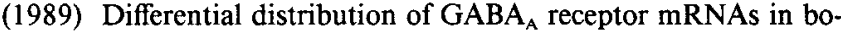
vine cerebellum - localization of $\alpha 2$ mRNA in Bergmann glia layer. Neurosci Lett 106:7-12.

Wisden W, Laurie DJ, Monyer H, Seeburg PH (1992) The distribution of $13 \mathrm{GABA}_{\mathrm{A}}$ receptor subunit mRNAs in the rat brain. I. Telencephalon, diencephalon, mesencephalon. J Neurosci 12:1040-1062.

Zhang N, Walberg F, Laake JH, Meldrum BS, Ottersen OP (1990) Aspartate-like and glutamate-like immunoreactivities in the inferior olive and climbing fibre system: a light microscopic and semiquantitative electron microscopic study in rat and baboon (Papio anubis). Neuroscience 38:61-80.

Zorumski CF, Thio LL (1992) Properties of vertebrate glutamate receptors: calcium mobilization and desensitization. Prog Neurobiol 39:295-336.

Zukin SR, Young AB, Snyder SH (1974) Gamma-aminobutyric acid binding to receptor sites in the rat central nervous system. Proc Natl Acad Sci USA 71:4802-4807. 